\title{
Evaluation of Bacteria Abundance and Sediment-Water Quality Parameters in a Spring Originated Shallow Pond Sediment
}

\author{
Serap Pulatsü ${ }^{1}$, Hikmet Katırcıoğlu ${ }^{2}$, Akasya Topçu ${ }^{1 *}$ and Doğukan Kaya ${ }^{1}$ \\ ${ }^{1}$ Department of Fisheries and Aquaculture, Faculty of Agriculture, Ankara University, \\ Ankara, Turkey \\ ${ }^{2}$ Department of Biology Education, Faculty of Education, Gazi University, Ankara, Turkey \\ *Corresponding author
}

\begin{tabular}{l} 
K e y w o r d s \\
$\begin{array}{l}\text { Sediment, Nitrification- } \\
\text { denitrification bacteria, } \\
\text { Most probable number } \\
\text { method, Sediment pore } \\
\text { water }\end{array}$ \\
\hline Article Info \\
$\begin{array}{l}\text { Accepted: } \\
\text { 04 May } 2018 \\
\text { Available Online: } \\
\text { 10 June } 2018\end{array}$ \\
\hline
\end{tabular}

A B S T R A C T
This study focused on a) determining spatial and temporal counts of bacteria using the Most Probable Number method (MPN), and b) evaluating the findings in terms of quality parameters of the sediment, sediment pore water and overlying water. Accordingly, surface sediment and water samples were taken at two stations located in areas of the pond, fed by groundwater polluted by agricultural runoff, with and without macrophytes in January, April, July and October 2017. It was determined that: a) while no statistically significant difference ( $p>0.05$ ) was seen in the numbers of nitrification bacteria between the stations located in areas with and without macrophytes, the numbers of denitrification bacteria varied according to location and month; b) as the nitrification and denitrification bacteria counts obtained at both stations in the sampling months were extremely low (11.021.50 cells $100 \mathrm{ml}^{-1}$ and $8.50-22.50$ cells $100 \mathrm{ml}^{-1}$, respectively), the bacteria did not play a sufficiently active role in the pond's nitrogen cycle; c) the negative sediment redox potential values $(-11.50$ and $-30.0 \mathrm{mV})$ prevented nitrifying bacteria activity; d) the low levels of denitrification bacteria detected may have been responsible for the low mineralization of the complex organic nitrogen in the sediment; e) there were no parallels between the numbers of nitrification bacteria and ammonium values in the sediment pore water, and the low levels of nitrification bacteria played a role in the ammonium concentrations in the water. Finally, macrophyte conservation and the reduction of the intensive agriculture practiced in the surrounding area could be suggested for the pondmanagement strategies.

\section{Introduction}

The nitrification and denitrification process in freshwater ecosystems, as in other aquatic ecosystems, is an important link in the nitrogen cycle. Nitrification, which is the microbial transformation of ammonium into nitrate, occurs in the aerobic layer of the sediment, which is the top $2-3 \mathrm{~mm}$; the thickness of this layer may vary according to the sediment's biological activity, dissolved oxygen concentration and the overlying water. Denitrification, on the other hand, a microbiological process in which nitrates in the sediment are reduced to molecular nitrogen $\left(\mathrm{N}_{2}\right)$ and then to nitrous oxide $\left(\mathrm{N}_{2} \mathrm{O}\right)$, 
requires nitrate, organic carbon and anoxic conditions (Delince, 1992). Microorganisms are responsible for the nitrogen cycle in lakes, and the bacteria that play a role in the nitrification-denitrification process have ecologic importance; moreover, environmental factors related to the receiving environment can directly affect the amounts and distribution of the bacteria groups that are part of the nitrogen cycle (Chen et al., 2009; Qiu et al., 2010; Zhang et al., 2016). Furthermore, the bacterial populations in the surface layer of the sediment and their metabolic activities are greater in number than those found in the overlying water (Wetzel, 2001).

The transfer into the water of nitrogen compounds, which exist as organic or inorganic compounds in the sediment, occurs either through diffusion via concentration differences or through bioturbation caused by organisms in the sediment. The inorganic nitrogen fractions ammonium, nitrate and nitrite ions are found either in the pore water or in a soluble form and Free State in absorbed colloids (Delince, 1992; Serpa et al., 2007). Inorganic nitrogen loading in aquatic ecosystems generally rises due to local agricultural activity, sewage, and anthropogenic atmospheric pollution. Nitratenitrogen in the soil, which can be adsorbed by plants, is not a stable structure but rather an extremely unstable ion. Because of this quality, the portion of nitrate-nitrogen that is not received by plants or bound to microorganisms is either lost via denitrification or carried to the receiving environment by surface currents after being easily washed from the surface soil and seeping into the ground water from the lower strata (Pulatsü et al., 2014).

Sakaryabaşı West Pond (Çifteler, Eskişehir Province), which is of karstic origin, is the main water source for a 25-ton rainbow trout farm; however, at times, the low dissolved oxygen levels and especially the high values of nitrogen fractions such as ammonia can reach amounts that threaten rainbow trout culture. Studies on the pond in recent years have examined the topics of nitrogenphosphorus fractions in the sediment and sediment pore water and nitrogen-phosphorus release from the sediment (Pulatsü et al., 2003; Topçu and Pulatsü, 2011; Topçu and Pulatsü, 2014). Accordingly, the present study aimed to prepare a scientific foundation upon which to base recommendations for management of the pond. With this purpose, a) the abundance of the bacteria in the stages of nitrification-denitrification, the key process in the sediment's nitrogen cycle, were determined according to month and station using the Most Probable Number method (MPN), and b) the amount of bacteria was discussed in terms of important parameters related to the overlying water, the pore water and the sediment.

\section{Materials and Methods}

\section{Study location}

Sakaryabaşı West Pond is located at an altitude of $880 \mathrm{~m}$; its perimeter measures $563 \mathrm{~m}$ and its area is $0.0092 \mathrm{~km}^{2}$ (Demir and Kırkağaç, 2005). The study was conducted at two stations chosen to represent areas with and without macrophytes in Sakaryabaşı West Pond (Figure 1). Sediment and water samples were taken from both stations in January, April, July and October 2017 in order to represent every season.

\section{Sediment sampling}

The surface sediment samples were taken with a sediment grab. The samples were placed in dark-colored plastic bags and transported to the laboratory via cooled transport. The redox potential values of the sediment samples were measured with a portable $\mathrm{pH}$ meter. 


\section{Overlying water sampling}

The overlying water samples were taken via siphon at about $10 \mathrm{~cm}$ above the sediment. The temperature and dissolved oxygen levels of the surface water and the overlying water were measured in the field with an oxygen meter, and the $\mathrm{pH}$ values were measured with a portable field-type $\mathrm{pH}$ meter.

\section{Determining the abundance of bacteria}

The Most Probable Number method (MPN) was used to estimate the population density of nitrification bacteria; for the samples from both stations $0.1 \mathrm{ml}, 1.0 \mathrm{ml}$ and $10.0 \mathrm{ml}$ dilutions were used. The Nitrosomanas and Nitrobacteria counts were performed according to Kıvanç et al., (2004); the isolation of the denitrifying bacteria from the sediment samples was performed as per Kıvanç et al., (2004) and Sarıüllü et al., (2007).

\section{Sediment analyses}

For the organic matter ratio (OM, \%): after the air-dried sediment samples were passed through a $0.5-\mathrm{mm}$ sieve, they were weighed before and after being heated at $550{ }^{\circ} \mathrm{C}$ for 2 hours, and the reduction in their weight was noted (Kacar, 1995). For the total organic carbon (TOC, \%) and total nitrogen (TN, \%) analyses, the Dumas method was used with an elemental analysis instrument; the total phosphorus ratio (TP, \%) was determined by the Vanadomolybdophosphoric yellow color method as indicated by Kacar and Inal (2008).

\section{Sediment pore water analyses}

The sediment pore water was separated from the sediment particles using a centrifuge at $5000 \mathrm{rpm}$ for a period of 10 minutes, and then removing the clear portion of water which had collected at the top of the test tubes with a pipette and filtering it through a $0.45 \mu \mathrm{m}$ membrane filter using a vacuum filter apparatus. The $\mathrm{pH}$ range was determined as 0 14 using a digital $\mathrm{pH}$ meter with a sensitivity of 0.01. Ammonium $\left(\mathrm{NH}_{4}{ }^{+}, \mathrm{mgL}^{-1}\right)$, nitrite $\left(\mathrm{NO}_{2}^{-}, \mathrm{mgL}^{-1}\right)$ and nitrate $\left(\mathrm{NO}_{3}^{-}, \mathrm{mgL}^{-1}\right)$ values were measured using the Nesslerization method, the $\alpha$-naphtylamine sulphanilic acid method and the Brucine sulphate method, respectively. The total filterable orthophosphate (SRP, $\mathrm{mgm}^{-3}$ ) values were determined according to the ascorbic acid method (APHA, 1995).

\section{Overlying water analyses}

After being filtered through a $0.45 \mu \mathrm{m}$ millipore membrane filter, the overlying water samples were kept at a temperature of $4^{\circ} \mathrm{C}$ until they were analyzed. The ammonium $\left(\mathrm{NH}_{4}{ }^{+}\right)$concentrations of these samples were determined using the Nesslerization method.

\section{Statistical analyses}

The statistical calculations and checking used in the evaluation of the data were performed according to the principles outlined by Kesici and Kocabaş (2007).

\section{Results and Discussion}

While the nitrification bacteria numbers in the pond sediment did not show a statistically significant difference between the stations with and without macrophytes, the numbers of denitrification bacteria varied according to both station and month $(\mathrm{p} \geq 0.05)$. Nitrification bacteria, which enable the biological transformation of the ammonia in the pond into nitrite and nitrate, were found in extremely low numbers (11.021.50 cells $100 \mathrm{ml}^{-1}$ ) in the four months in which the sampling was performed. Denitrification bacteria, which are responsible for the denitrification process, in which nitrate 
is reduced to nitrous oxide, were similarly found in very low numbers $(8.50-22.50$ cells $100 \mathrm{ml}^{-1}$ ) (Figure 2). The fact that both nitrification and denitrification numbers were found to be extremely low during the sample months indicates that the nitrogen cycle carried out by bacteria in West Pond is not in a healthy state.

Variations in the values of the sediment's organic matter, total nitrogen, total phosphorus and total organic carbon according to month and station are shown in Table.2. The sediment nutrients (TN, TP and TOC) were found in higher levels at the station without macrophytes. It appears that the high nitrate concentrations $\left(7.68-8.96 \mathrm{mgL}^{-1}\right)$ in the overlying water and the high level of organic matter $(17.07-22.81 \%)$ in the sediment of West Pond are two key components of denitrification; this is in accordance with Arango et al., (2007) and Zhang et al., (2010)'s findings regarding the elements shown to be active in the denitrification process in different aquatic ecosystems. When the ammonium values in the sediment pore water at the station with macrophytes and the organic matter levels in the sediment are taken into account, it can be said that nitrogen mineralization generally shows a positive correlation with the sediment's organic matter content. However, as denitrification bacteria were found at low concentrations in the pond, it is thought that nitrogen fractions in the environment increased and that organic matter did not play a major role in oxidation.

The lowest values for redox potential in the sediment of West Pond (-11.50 and $-30.0 \mathrm{mV}$ ) were found in July and October at both stations; the highest values were measured as $49.50 \mathrm{mV}$ in April at the station with macrophytes (Station I) and in January at the station without macrophytes (Station II). Moreover, the negative redox potential values measured at both stations in July and October raise the possibility of a negative effect on the amount of nitrification bacteria (11.012.50 cells $100 \mathrm{ml}^{-1}$ ), and the fact that the nitrate values in the sediment pore water were determined to be lower in these months than in the other months supports the idea that negative redox potential values negatively affect the nitrification process. It has been reported that low redox potential in the sediment triggers denitrification (Weisner et al., 1994), and that denitrification activity is increased in sediments in littoral areas or in the lower sections $(10-15 \mathrm{~mm})$ of sediment with increased reductive conditions $\left(\mathrm{E}_{\mathrm{h}} \leq\right.$ $\leq 210210 \mathrm{mV}$ ) due to surface pressure on sediments that are in contact with oxygenated water (Wetzel, 2001).

It has been reported that at high temperatures, organic material collects in the uppermost layer of the sediment, and due to elevated microbial metabolism, the rate of mineralization increases, causing an increase in ammonium in the pore water during warm periods (Serpa et al., 2007). However, at both of the selected stations in the pond, there was an inverse relationship between the ammonium concentrations in the sediment pore water and the numbers of nitrification bacteria in the sediment; the fact that ammonium concentrations in the sediment pore water reached high levels in July and October (2.36-3.68 $\mathrm{mgL}^{-1}$; Table 1) was evaluated according to the premise that the water temperature in the pond, which did not show great variation according to month, did not affect microbial activity.

The concentrations of nitrification bacteria in the sediment of West Pond and the fact that high concentrations of nitrate were observed in the sediment pore water in the winter and spring months supports the idea that the nitrogen fractions retained by dying or decaying macrophytes can enter the sediment pore water. 
Table.1 Monthly mean concentrations of inorganic nitrogen fractions and soluble reactive phosphorus in pore water West Pond

\begin{tabular}{|c|c|c|c|}
\hline \multirow[t]{2}{*}{ Parameter } & \multirow[t]{2}{*}{ Month } & \multicolumn{2}{|c|}{ Station } \\
\hline & & I & II \\
\hline \multirow[t]{4}{*}{$\mathrm{NH}_{4}\left(\mathrm{mg} \mathrm{L}^{-1}\right)$} & January & $1,31 \pm 0,00^{\mathrm{Ca}}$ & $0,68 \pm 0,01^{\mathrm{Db}}$ \\
\hline & April & $1,25 \pm 0,00^{\mathrm{Da}}$ & $1,45 \pm 0,00^{\mathrm{Cb}}$ \\
\hline & July & $1,97 \pm 0,01^{\mathrm{Ba}}$ & $3,68 \pm 0,04^{\mathrm{Ab}}$ \\
\hline & October & $2,36 \pm 0,00^{\mathrm{Aa}}$ & $2,11 \pm 0,01^{\mathrm{Bb}}$ \\
\hline \multirow[t]{4}{*}{$\mathrm{NO}_{2}\left(\mathrm{mg} \mathrm{L}^{-1}\right)$} & January & $0,04 \pm 0,00^{\mathrm{Ca}}$ & $0,02 \pm 0,00^{\mathrm{Bb}}$ \\
\hline & April & $0,01 \pm 0,00^{\mathrm{Da}}$ & $0,02 \pm 0,00^{\mathrm{Bb}}$ \\
\hline & July & $0,13 \pm 0,00^{\mathrm{Aa}}$ & $0,03 \pm 0,00^{\mathrm{Ab}}$ \\
\hline & October & $0,07 \pm 0,00^{\mathrm{Ba}}$ & $0,03 \pm 0,00^{\mathrm{Ab}}$ \\
\hline \multirow[t]{4}{*}{$\mathrm{NO}_{3}\left(\mathrm{mg} \mathrm{L}^{-1}\right)$} & January & $5,32 \pm 0,00^{\mathrm{Aa}}$ & $6,43 \pm 0,00^{\mathrm{Ab}}$ \\
\hline & April & $5,03 \pm 0,00^{\mathrm{Ca}}$ & $5,37 \pm 0,01^{\mathrm{Bb}}$ \\
\hline & July & $3,02 \pm 0,01^{\mathrm{Da}}$ & $3,75 \pm 0,00^{\mathrm{Cb}}$ \\
\hline & October & $5,08 \pm 0,01^{\mathrm{Ba}}$ & $2,35 \pm 0,00^{\mathrm{Db}}$ \\
\hline \multirow[t]{4}{*}{$\operatorname{SRP}\left(\mathrm{mg} \mathrm{L}^{-1}\right)$} & January & $0,038 \pm 0,003^{\mathrm{Ba}}$ & $0,015 \pm 0,004^{\mathrm{Bb}}$ \\
\hline & April & $0,012 \pm 0,000^{\mathrm{Ca}}$ & $0,009 \pm 0,005^{\mathrm{BCb}}$ \\
\hline & July & $0,012 \pm 0,000^{\mathrm{Ca}}$ & $0,019 \pm 0,003^{\mathrm{Bb}}$ \\
\hline & October & $0,078 \pm 0,002^{\mathrm{Aa}}$ & $0,051 \pm 0,005^{\mathrm{Ab}}$ \\
\hline
\end{tabular}

Table.2 Monthly mean physico-chemical concentrations of overlying water in West Pond

\begin{tabular}{|c|c|c|c|}
\hline \multirow[t]{2}{*}{ Parameter } & \multirow[t]{2}{*}{ Month } & \multicolumn{2}{|c|}{ Station } \\
\hline & & I & II \\
\hline \multirow[t]{4}{*}{$\mathrm{NH}_{4}\left(\mathrm{mg} \mathrm{L}^{-1}\right)$} & January & $1,65 \pm 0,00^{\mathrm{Da}}$ & $1,52 \pm 0,00^{\mathrm{Db}}$ \\
\hline & April & $2,46 \pm 0,02^{\mathrm{Ca}}$ & $3,21 \pm 0,01^{\mathrm{Ab}}$ \\
\hline & July & $3,57 \pm 0,00^{\mathrm{Ba}}$ & $1,66 \pm 0,00^{\mathrm{Cb}}$ \\
\hline & October & $4,62 \pm 0,02^{\mathrm{Aa}}$ & $2,43 \pm 0,01^{\mathrm{Bb}}$ \\
\hline \multirow[t]{4}{*}{$\mathrm{NO}_{2}\left(\mathrm{mg} \mathrm{L}^{-1}\right)$} & January & $0,03 \pm 0,00^{\mathrm{Ca}}$ & $0,02 \pm 0,00^{\mathrm{Db}}$ \\
\hline & April & $0,02 \pm 0,00^{\mathrm{Da}}$ & $0,03 \pm 0,00^{\mathrm{Cb}}$ \\
\hline & July & $0,04 \pm 0,00^{\mathrm{Ba}}$ & $0,07 \pm 0,00^{\mathrm{Bb}}$ \\
\hline & October & $0,05 \pm 0,01^{\mathrm{Aa}}$ & $0,29 \pm 0,01^{\mathrm{Ab}}$ \\
\hline \multirow[t]{4}{*}{$\mathrm{NO}_{3}\left(\mathrm{mg} \mathrm{L}^{-1}\right)$} & January & $7,68 \pm 0,01^{\mathrm{Aa}}$ & $8,96 \pm 0,01^{\mathrm{Ab}}$ \\
\hline & April & $5,96 \pm 0,00^{\mathrm{Ba}}$ & $7,23 \pm 0,00^{\mathrm{Bb}}$ \\
\hline & July & $4,12 \pm 0,00^{\mathrm{Da}}$ & $6,03 \pm 0,00^{\mathrm{Db}}$ \\
\hline & October & $4,67 \pm 0,01^{\mathrm{Ca}}$ & $6,39 \pm 0,00^{\mathrm{Cb}}$ \\
\hline \multirow[t]{4}{*}{ SRP $\left(\mathrm{mg} \mathrm{L}^{-1}\right)$} & January & $0,040 \pm 0,001^{\mathrm{Ba}}$ & $0,042 \pm 0,001^{\mathrm{Aa}}$ \\
\hline & April & $0,035 \pm 0,001^{\mathrm{Ca}}$ & $0,034 \pm 0,001^{\mathrm{Ba}}$ \\
\hline & July & $0,044 \pm 0,001^{\mathrm{Aa}}$ & $0,043 \pm 0,001^{\mathrm{Aa}}$ \\
\hline & October & $0,039 \pm 0,001^{\mathrm{Ba}}$ & $0,044 \pm 0,001^{\mathrm{Aa}}$ \\
\hline \multirow[t]{4}{*}{ Temperature $\left({ }^{\circ} \mathrm{C}\right)$} & January & $17,08 \pm 0,05^{\mathrm{Da}}$ & $17,10 \pm 0,04^{\mathrm{Da}}$ \\
\hline & April & $19,32 \pm 0,05^{\mathrm{Ba}}$ & $19,25 \pm 0,03^{\mathrm{Bb}}$ \\
\hline & July & $20,10 \pm 0,04^{\mathrm{Aa}}$ & $19,83 \pm 0,03^{\mathrm{Ab}}$ \\
\hline & October & $18,55 \pm 0,03^{\mathrm{Ca}}$ & $18,37 \pm 0,025^{\mathrm{Cb}}$ \\
\hline \multirow[t]{4}{*}{$\mathbf{p H}$} & January & $5,75 \pm 0,00^{\mathrm{Da}}$ & $5,80 \pm 0,00^{\mathrm{Db}}$ \\
\hline & April & $6,08 \pm 0,03^{\mathrm{Ca}}$ & $6,20 \pm 0,01^{\mathrm{Cb}}$ \\
\hline & July & $6,67 \pm 0,01^{\mathrm{Aa}}$ & $6,78 \pm 0,00^{\mathrm{Ab}}$ \\
\hline & October & $6,62 \pm 0,00^{\mathrm{Ba}}$ & $6,61 \pm 0,01^{\mathrm{Bb}}$ \\
\hline \multirow[t]{4}{*}{ DO $\left(\mathrm{mg} \mathrm{L}^{-1}\right)$} & January & $4,79 \pm 0,05^{\mathrm{Ba}}$ & $4,89 \pm 0,03^{\mathrm{Ba}}$ \\
\hline & April & $6,69 \pm 0,03^{\mathrm{Aa}}$ & $5,96 \pm 0,07^{\mathrm{Ab}}$ \\
\hline & July & $3,52 \pm 0,16^{\mathrm{Da}}$ & $3,09 \pm 0,06^{\mathrm{Db}}$ \\
\hline & October & $4,34 \pm 0,01^{\mathrm{Ca}}$ & $4,26 \pm 0,02^{\mathrm{Cb}}$ \\
\hline
\end{tabular}


Fig.1 Sampling stations (I ${ }^{\text {st }}$ station: $39^{\circ} 21^{\prime} 17^{\prime \prime} N-31^{\circ} 03^{\prime} 26^{\prime \prime} E$, with macrophytes; II ${ }^{\text {nd }}$ station: $39^{\circ} 21^{\prime} 17^{\prime \prime N}-31^{\circ} 03^{\prime} 27^{\prime \prime E}$, without macrophytes)

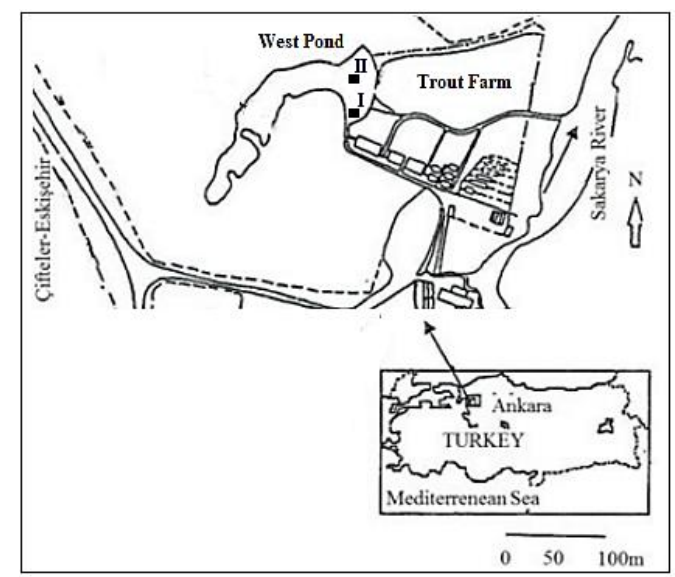

Fig.2 Monthly mean sediment quality parameters and abundance of nitrification denitricifation bacteria in West Pond

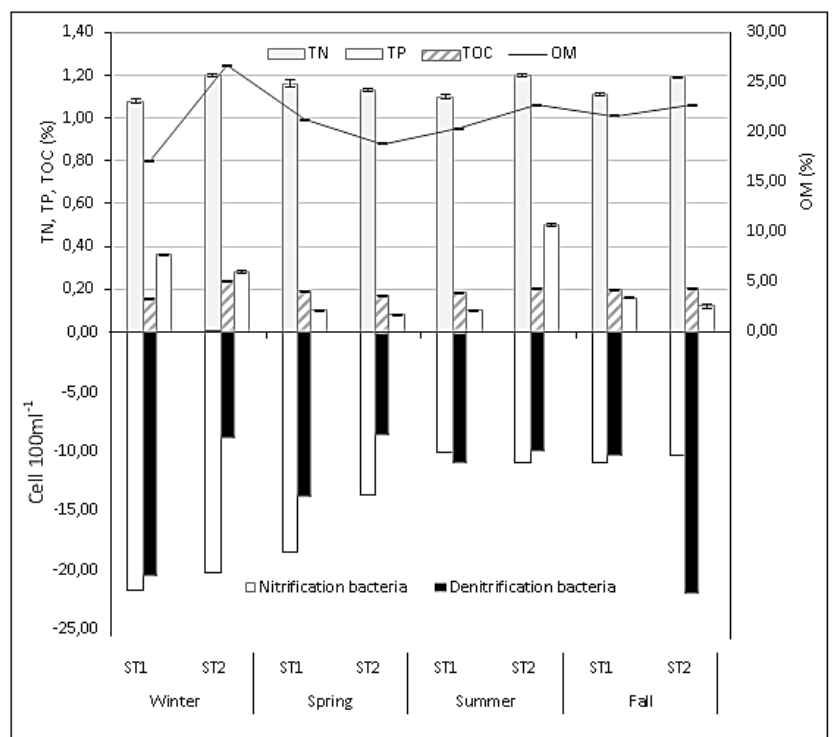

The ammonium values in the overlying water at the station with macrophytes were found to be higher than at the station without macrophytes, except for in April. Nitrate concentrations in the overlying water were at minimum values during the summer, and were found to be lower at the station with macrophytes than at the station without macrophytes in all the months in which samples were taken (Table 2). It is thought that this condition is associated with the use of nitrate by algae and aquatic plants. The fact that in the overlying water in January, unlike nitrate values, ammonium values were at minimum levels, points to nitrification. The fact that in April at the study station without macrophytes both oxygen concentrations $\left(5.96 \mathrm{mgL}^{-1}\right)$ and ammonium concentrations (3.21 $\mathrm{mgL}^{-1}$ ) were high indicates that as a nitrogen source, the phytoplankton group did not consume ammonium. The fact that in West Pond, due to its short refreshing period, 
there are low phytoplankton concentrations and high macrophyte and macroalgae concentrations (Demir and Kırkağaç, 2005) causes us to think that the above-mentioned aquatic plants do not play a significant role in the biological assimilation of ammonium. The fact that the high concentrations of nitrate in the pond water were found to be at a minimum in July indicates that the removal of nitrates from the water column which normally occurs with denitrification is suppressed during the summer.

In the study, the ammonium and nitrate concentrations in the overlying water were observed to be higher than the values for these fractions in the sediment pore water. This finding is in accordance with Fulweiler et al., (2008)'s finding that the increase of organic and inorganic nutritive element concentrations in the overlying water put the sediment in the position of being a net trap.

The fact that in West Pond, the nitrification bacteria, which play a key role in the nitrification process in the surface sediment, were found at very low levels negatively affects the active nitrification process. Because the redox potential values in the surface sediment of the pond were negative, particularly in the summer and autumn months, the nitrifying bacteria were not localized in the sediment, and the above parameter appears to be a factor in the hindrance of these activities. The low concentrations of nitrifying bacteria in the sediment negatively affect the rate of nitrification, and this situation opens a path to the increase of ammonium concentrations in the pond water.

In the denitrification process, which is important in permanently removing nitrogen from the pond, the high levels of carbon in the sediment and the organic matter content play a role as a carbon source in denitrification and lay a foundation for anoxic conditions, which stimulate denitrification. In contrast to the prediction that macrophytes in the pond would support the denitrification process through their organic carbon uptake, it is thought that denitrification bacteria, which were found in extremely low numbers, do not play an important role in the mineralization of organic matter. Additionally, the low TOC/TN ratio in the sediment (3.38-4.32) indicates the low mineralization of complex organic nitrogen in the sediment.

The fact that the ammonium and nitrate values in the overlying water of the pond were higher than the values for these fractions in the sediment pore water supports the idea that the nutrients in the sediment act as a trap.

The Phragmites spp. beds found in West Pond, especially in the littoral areas, are known to retain nitrogen and phosphorus in concentrated from in their roots and stems; and the fact that these macrophytes take and store these nutrients over the long term makes them an important component in the eutrophication process. Thus, rather than completely removing the macrophytes from the pond, seasonal harvesting seems to be a good option for the pond management.

In order to improve the quality of the water and soil and increase the microbial population in ponds where aquaculture is practiced, infusions of live bacteria and enzyme combinations are used. These bacteria include cellulose disintegrating bacteria, nitrificationdenitrification bacteria and sulphite oxidizing bacteria, among others. However, these types of applications can have certain negative effects on water quality, such as increasing ammonia and $\mathrm{pH}$ levels, and disadvantages such as economic sustainability which must be taken into consideration; comprehensive testing of the applications must be done before applying these methods. 
According to the tritium isotope content of West Pond (Kirkgiz Spring), which flows into Sakaryabaş1, the aquifer circulation period has been reported as 5.5-8 years (Güven, 1996). When the heavy agricultural activity in the vicinity of West Pond is considered, the high nitrate amounts carried into the groundwater that feeds the pond when nitrogen fertilizers wash from the soil and the negative effect of the large number of wells on the groundwater reserve cannot be overlooked. Accordingly, in light of the continuation of the pond's ecologic functions, especially the sustainability of the rainbow trout culture, and the control of the outside sources of nitrogen loading in the pond's environment, it is extremely urgent that action to prevent agricultural pollution, which is one of the main sources of organic pollution in the area.

\section{Acknowledgements}

We greatly thank the financial support by the Research Foundation of Ankara University, Grant No: 17B0759001.

\section{References}

APHA, 1995. Standard Methods for the Examination of Water and Wastewater, Ed: John D., Ducas Co., USA, Pp: 1193.

Arango, C.P., Tank, J.L, Schaller, J.L., Royer, T.V., Bernot M.J., and David, M.B. 2007. Benthic organic carbon influences denitrification in streams with high nitrate concentration. Freshwater Biology. 52: 1210-1222.

Barlas, M. 2017. Azot Döngüsü. Limnoloji Göl ve Nehir Ekosistemleri. 3. Basımdan Çeviri. (Eds) M. Borga Ergönül. Nobel Yayın Dağıtım, Türkiye. Pp. 205-237 (in Turkish).

Chen, G, Y., Qiu, S, L., and Zhou, Y, Y. 2009. Diversity and abundance of ammonia-oxidizing bacteria in eutrophic and oligotrophic basins of a shallow Chinese Lake (Lake Donghu). Research in Microbiology. 160: 173178.

Delince, G. 1992. The Ecology of the Fish Pond Ecosystem. Kluwer Academic Publishers, Netherlands, Pp: 230.

Demir, N., and Kırkağaç, M. 2005. Plankton Composition and Water Quality in a Spring Origin in Turkey.Limnology. 6: 189-194,

Fulweiler, R. W., Nixon, S. W., Buckley, B. A., and Granger, S. L. 2008. Net sediment $\mathrm{N}_{2}$ fluxes in a coastal marine system-experimental manipulations and a conceptual model. Ecosystems. 11: 1168-1180.

Güven, F. 1996. Sakaryabaşı Kaynaklarının Çevresel İzotop İncelemesi, H.Ü. Fen Bilimleri Enstitüsü Jeoloji (Hidrojeoloji) Ana Bilim Dalı Yüksek Mühendislik Tezi, 118s (in Turkish).

Kacar, B. 1995. Bitki ve Toprağın Kimyasal Analizleri 3: Toprak Analizleri, Ankara Üniversitesi Ziraat Fakültesi Eğitim Araştırma ve Geliştirme Vakfi Yayınları, No: 3, Ankara (in Turkish).

Kacar, B. and İnal, A. 2008. Bitki Analizleri.Nobel Yayın Dağıtım, Ankara (in Turkish).

Kesici, T.,and Kocabaş, Z. 2007. Biyoistatistik, Ankara Üniv. Eczacilık Fakültesi Yayın No: 94, Ankara (in Turkish).

Kıvanç, M., Güven K., Uçan, N, K., Sarıözlü, N, Y., Mutlu, M, B. and Yilmaz M. 2004. Porsuk Çayı'nda azot miktarı ve nitrifikasyon bakterilerinin dağılımı. Mikrobiyoloji Dergisi. 2: 2-11 (in Turkish).

Pulatsü, S., Akçora, A., and Köksal, F. 2003. Sediment and Water Phosphorus Characteristics in a Pond of Spring Origin, Sakaryabaşı Springs Basin, Turkey.Wetlands. 23(1): 200-204. 
Pulatsü, S., Topçu, A. and Atay, D. 2014. Su Kirlenmesi ve Kontrolü (Genişletilmiş İkinci Bask1). Ankara Üniversitesi Ziraat Fakültesi Yayın No: 1617, Ders Kitab1: 569 (in Turkish).

Qui, S., Chen, G., and Zhou, Y. 2010. Abundance and diversity of ammoniaoxidizing bacteria in relation to ammonium in an Chinese shallow eutrophic urban lake.Brazilian Journal of Microbiology. 41: 218-226.

Sarıü̈llü, F.E. 2007. Doğal ortamlardan denitrifikasyon yetenegi yüksek bakteri izolasyonu ve denitrifikasyonda kullanılabilirliklerinin araştırılması. Çukurova Üniversitesi, Fen Bilimleri Enstitüsü, Y.L. Tezi. s. 69 (in Turkish).

Serpa, D., Falcao, M., Duarte, P., Fonseca, C., and Vale, C. 2007. Evaluation of the ammonium and phosphate release from intertidal and subtidal sediments of a shallow coastal lagoon (Ria formosaPortugal): a modelling approach.Biogeochemistry. 82(3): 291304.

Topçu, A., and Pulatsü, S. 2014. Phosphorus fractions and cycling in the sediment of a shallow eutrophic pond.Journal of Agricultural Sciences. 20 (1): 63-70.

Topçu, A.,and Pulatsü, S. 2011. Sakaryabaşı (Çifteler-Eskişehir) Balık Üretim ve Araştırma İstasyonu `nun su kaynağı Bat1 Göleti: Sediment kaynaklı inorganik azot salınımının araştırılması. Ekoloji. 20(78): 26-33 (in Turkish).

Weisner, S. E. B., Peder, G. E., Graneli, W., and Leonardson, L. 1994. Influence of macrophytes on nitrate removal in wetlands.Ambio. 23 (6): 363-366.

Wetzel, R.G. 2001. Limnology: Lake and River Ecosystems. Academic Press; 3 edition, UK, Pp: 1006.

Zhang, J., Fan, C., Liu, G., Zhang, L., Shang, J., Gu, X. 2010. Seasonal variation of potential denitrification rates of surface sediment from Meiliang Bay, Taihu Lake, China.Journal of Environmental Sciences. 22 (7): 961-967.

Zhang, Y., Ruan, X., Wan, Y., and Li, X. 2016. Effect of environmental factors on anammox bacterial community structure in sediments of a freshwater aquaculture farm, Yangcheng Lake. Geomicrobiology Journal.33 (6): 479487.

\section{How to cite this article:}

Serap Pulatsü, Hikmet Katırcıŏlu, Akasya Topçu and Doğukan Kaya. 2018. Evaluation of Bacteria Abundance and Sediment-Water Quality Parameters in a Spring Originated Shallow Pond Sediment. Int.J.Curr.Microbiol.App.Sci. 7(06): 784-792. doi: https://doi.org/10.20546/ijcmas.2018.706.091 